\title{
Prevalence of BK virus among renal transplant recipients in a tertiary care hospital in Sri Lanka
}

\author{
M I Premathilake ${ }^{1,2}$, J S Jayamaha ${ }^{2}$, R D Lanerolle ${ }^{1}$ \\ (Index words: BK virus, Polyomavirus, nephropathy, Sri Lanka, renal transplantation)
}

\begin{abstract}
Introduction BK virus nephropathy (BKVN) is an important cause of graft failure in post renal transplant patients. Detection of BK virus replication early enables prevention of BK virus nephropathy. Understanding BK virus epidemiology in post renal transplant patients will be useful in implementing a routine screening programme.
\end{abstract}

Objectives Objectives were to determine the prevalence of BK virus viruria and viraemia among post renal transplant patients within the first two years of transplantation.

Methodology A hospital-based, descriptive crosssectional study was conducted on 136 clinic and inward patients. Plasma and urine were tested for BK virus DNA using real time PCR. Serum creatinine done within two weeks of data collection was recorded.

Results The prevalence of BK virus viruria was $53.67 \%$ and viraemia was $11 \%$. Viraemia $>1000$ copies $/ \mathrm{ml}$ was associated with abnormal serum creatinine and higher median serum creatinine. No similar association was observed with viruria. Among patients with normal serum creatinine, virus was not detected in urine in $48.9 \%$ and plasma in $92.7 \%$.

Conclusions The prevalence of BK virus is high in this study population. Significant viraemia was associated with elevated serum creatinine. Viruria or viraemia was not detected among a large number of patients with normal serum creatinine.

Ceylon Medical Journal 2018; 63: 124-128

DOI: http://doi.org/10.4038/cmj.v63i3.8716

\section{Introduction}

$\mathrm{BK}$ virus (BKV) is a DNA virus belonging to the family polyomaviridae. It commonly causes mild infections during childhood. Following primary infection, the virus becomes latent primarily in the uro-epithelium.
Spontaneous reactivation of virus can occur in immunocompetent hosts but is commoner during immunosuppression. The most serious complication due to $\mathrm{BK}$ virus reactivation among renal transplant recipients is BK virus associated nephropathy, occurring in 1-10\% of renal transplant recipients [1]. Progressive BK virus associated nephropathy may lead to graft failure and graft loss in $10-100 \%$ of cases [2].

BK virus associated nephropathy is typically diagnosed within the first year post-transplantation, although approximately $25 \%$ of the cases are seen later [2]. BK virus associated nephropathy lacks any specific clinical features and is characterized by rising serum creatinine levels, absence of histological evidence of graft rejection and presence of obstructive uropathies as hydronephrosis and or hydroureter [2]. BK virus associated nephropathy should be clinically suspected in patients with unexplained rising serum creatinine. Due to lack of clinical clues, early detection of viral replication is crucial to prevent progression of infection to BK virus associated nephropathy. Quantitative real-time polymerase chain reaction (PCR) assay for BK virus in urine and blood are the commonest screening tools, however universal cutoff points are not yet established. Urine BK virus load $>10^{7}$ copies $/ \mathrm{ml}$ or plasma $\mathrm{BK}$ virus load $>10^{4} \mathrm{copies} / \mathrm{ml}$ are used commonly as surrogate markers for BK virus associated nephropathy. Definitive diagnosis of BK virus associated nephropathy could be made only by an allograft biopsy using histopathology and immunohistochemistry. Reduction of immuno-suppression is the corner stone of management of BK virus associated nephropathy although it always carries a risk of graft rejection. Due to the lack of successful therapeutic options, implementation of preventive strategies plays a key role in preventing graft loss due to BK virus infection. In Sri Lanka the number of kidney transplantations performed are increasing each year. Infectious complications as BK virus associated nephropathy may increase the healthcare costs and requirement for resources, which could be very challenging. Knowledge about the epidemiology of BK

${ }^{1}$ Faculty of Medicine, University of Colombo, ${ }^{2}$ Medical Research Institute, Colombo, Sri Lanka.

Correspondence: MIP, e-mail: <isharap@micro.cmb.ac.lk>. Received 05 June 2018 and revised version accepted 3 July 2018.

(i) This is an open-access article distributed under the terms of the Creative Commons Attribution License, which permits unrestricted use, distribution, and reproduction in any medium, provided the original author and source are credited. 
virus infection is important in making policy decisions regarding screening for BK virus reactivation among these patients. The aims of this study were to describe the prevalence of BK virus viruria and viraemia among the study population and the associated factors.

\section{Methodology}

Study design

Hospital based descriptive cross-sectional study was carried out on all post renal transplant patients within two years of transplantation, who were in-ward patients or attending clinics of University Medical Unit and National Renal Transplantation Unit, National Hospital of Sri Lanka. All consenting patients were enrolled consecutively, from July to October 2015. Patients on heparin were excluded.

\section{DNA extraction}

DNA was extracted from both plasma and whole urine using the QIAmp® Viral RNA minikit by QIAGEN according to the manufacturer's instructions.

\section{Real-time PCR assay}

BK virus real-time PCR was carried out using the Altona Real-star ${ }^{\circledR}$ BK VIRUS assay according to the manufacturer's instructions. The kit has an analytical sensitivity of 0.712 copies/ $\mu 1$ ( $95 \%$ CI 0.404 - 1.693 copies $/ \mu l$ ), linear range $1.00 \mathrm{E}+09$ to $1.00 \mathrm{E}+00$ copies $/ \mu \mathrm{l}$.

\section{Data collection}

Data was collected using a pre-tested interviewer administered questionnaire. Clinical data included the exact period after transplantation, immunosuppressive treatment and recent serum creatinine done within two weeks of data collection.

\section{Data analysis}

Viriuria and viraemia were defined as detection of virus in urine and plasma respectively. Data was categorized according to the cut-points given in table 1 [1].

\section{Table 1. Categorization of patients according to detection of virus in urine/plasma}

\begin{tabular}{lll}
\hline Category & Urine & Plasma \\
\hline Virus not detected & Aviruric & Aviraemic \\
Virus detected & Viruric & Viraemic \\
& $(<2500$ copies/ml $)$ & $(<1000 \mathrm{copies} / \mathrm{ml})$ \\
Significant & & \\
viruria/viraemia & Viruria & Viraemia \\
& $\geq 2500$ copies $/ \mathrm{ml}$ & $\geq 1000 \mathrm{copies} / \mathrm{ml}$ \\
\hline
\end{tabular}

Abnormal serum creatinine was defined as $>1.5 \mathrm{mg} /$ $\mathrm{dl}$ for both sexes.

\section{Statistical analysis}

Patients with different amounts of viruria and viraemia were compared using non parametric tests. Categorical variables were analysed using chi-square test with analysis of adjusted residual values. Statistical analysis was done using SPSS 21.0 (Illinois USA).

\section{Ethical issues}

Ethical approval was obtained from the Ethics Review Committee, Medical Research Institute, Colombo (16/2014). Written informed consent was obtained from all patients.

\section{Results}

Among the 136 participants $59.6 \%$ were male (Table 2 ). The mean age was 40.65 years (SD 14.2). Majority of the patients $(n=104 ; 76.5 \%$, ) were on triple immunosuppression with prednisolone, mycophenolate mofetil and tacrolimus.

Earliest time to detect significant viruria and viraemia was one month post transplantation. The median post transplantation time for virus detection was 8 months in urine (IQR 3.38-13.5) and plasma (IQR 4-24).

\section{Table 2. Characteristics of the post renal transplant patients}

\begin{tabular}{ll}
\hline & Number (\%) \\
\hline Age (years) & 40.65 (SD 14.2) \\
Gender & $81(59.6)$ \\
Male & $50(40.4)$ \\
Female & \\
Setting & $19(13.9)$ \\
In-patient & $117(86.1)$ \\
Clinic & $104(76.5)$ \\
Triple immunosuppression & \\
Mean daily dose & $10.4 \mathrm{mg}(\mathrm{SD} 6.7)$ \\
Prednisolone & $1397.63 \mathrm{mg}(\mathrm{SD} 282.34)$ \\
MMF & 5.24 (SD 1.58) \\
Tacrolimus & 35 (26.7) \\
Elevated serum creatinine $(>1.5 \mathrm{mg} / \mathrm{dl})$ & $96(73.3)$ \\
Normal serum creatinine $(\leq 1.5 \mathrm{mg} / \mathrm{dl})$ &
\end{tabular}

\section{$B K$ virus viruria}

$\mathrm{BK}$ virus was detected in the urine in $73(53.7 \%)$ patients. Among the viruric patients, 36 $(26.5 \%)$ had viruria $<2500$ copies/ml and $37(27.2 \%)$ had viruria $\geq 2500$ copies/ $\mathrm{ml}$; seven had viruria $\geq 10^{7}$ copies $/ \mathrm{ml}$. The median urine viral load among viruric patients was 2794.5 copies/ml (IQR 244.3 - 260,000). 


\section{$B K$ virus viraemia}

Viraemia was detected in $15(11 \%)$ patients. Among them $11(8 \%)$ had significant viraemia with $\geq 1000$ copies/ $\mathrm{ml}$ including two patients with viraemia $>10^{4}$ copies $/ \mathrm{ml}$. Median plasma viral load among viraemic patients was 3038 copies/ml (IQR 678 - 6023). Both patients with viraemia $>10^{4}$ copies $/ \mathrm{ml}$ had viruria $\geq 10^{7}$ copies $/ \mathrm{ml}$. All patients except one with viruria $\geq 10^{7}$ copies $/ \mathrm{ml}$, had viraemia $>1000$ copies $/ \mathrm{ml}$. The remaining patient had 462 copies $/ \mathrm{ml}$.

Association between serum creatinine and urine and plasma viral load

Elevated serum creatinine was detected in 35 out of 131 patients. Median serum creatinine was compared according to viruria and viraemia load (Table 3 ). There was no statistically significant difference in median serum creatinine in the according to amount of viruria $(\mathrm{p}=0.07)$. However, median serum creatinine was associated with the amount viraemia $(\mathrm{p}=0.013)$. Post hoc analysis showed that the significant difference was between the $1^{\text {st }}$ and the $3^{\text {rd }}$ groups $(\mathrm{p}=0.022)$.
Table 3. Median serum creatinine levels according to amount of viruria

BK virus load

Median serum creatinine level $\mathrm{mg} / \mathrm{dl}(\mathrm{IQR})$

Urine

Aviruric

$1.11(0.93-1.4)$

$<2500$ copies/ml

$\geq 2500$ copies $/ \mathrm{ml}$

Plasma

Aviraemic

$1.08(0.93-1.36)$

$<1000$ copies/ml

$\geq 1000$ copies $/ \mathrm{ml}$

$1.38(1.2-1.48)$

No significant association between normal and abnormal serum creatinine and amount of viruria (Table 4).

Table 4. Normal and abnormal serum creatinine according to amount of viruria

\begin{tabular}{lllll}
\hline & $\begin{array}{l}\text { Aviriuric } \\
\text { Number }(\%)\end{array}$ & $\begin{array}{l}\text { Viraemia } \\
<2500 \text { copies } / m l \\
\text { Number }(\%)\end{array}$ & $\begin{array}{l}\text { Viraemia } \\
\geq 2500 \text { copies } / m l \\
\text { Number }(\%)\end{array}$ & Total \\
\hline Normal serum creatinine & $47(74.60)$ & $23(71.87)$ & $26(72.22)$ & 96 \\
Abnormal serum creatinine & $16(25.40)$ & $9(28.13)$ & $10(27.78)$ & 35 \\
Total & 63 & 32 & 36 & 131 \\
\hline
\end{tabular}

A significantly higher proportion of patients with viraemia $\geq 1000$ copies $/ \mathrm{ml}$ had abnormal serum creatinine, compared to those who were aviraemic (adjusted residual values) $(\mathrm{p}=0.015)$ (Table 5). Both patients who had high level of viraemia (>10000 copies/ml) had abnormal serum creatinine.

Table 5. Normal and abnormal serum creatinine according to viraemia categories

\begin{tabular}{lllll}
\hline & $\begin{array}{l}\text { Aviriuric } \\
\text { Number (\%) }\end{array}$ & $\begin{array}{l}\text { Virus } \\
\text { detected } \\
\text { Number (\%) }\end{array}$ & $\begin{array}{l}\geq 1000 \text { copies/ml } \\
\text { Number (\%) }\end{array}$ & Total \\
\hline Normal serum creatinine & $89(76.73)$ & $3(75.0)$ & $4(36.36)$ & 96 \\
Abnormal serum creatinine & $27(23.27)$ & $1(25.0)$ & $7(63.64)$ & 35 \\
Total & 116 & 4 & 11 & 131 \\
\hline
\end{tabular}


Background viral loads in patients with normal serum creatinine

Urine BK virus was not detectable in 47/96 (48.9\%) patients with normal serum creatinine. The median urine viral load was 9.9 copies/ml (IQR 0-2887 copies/ml). BK virus was not detected in plasma in $82(92.7 \%)$ patients and the values in viraemic patients were beyond the 75 th percentile (median and IQR were 0 ).

\section{Discussion}

This is the first prevalence study carried out in Sri Lanka on BK virus infection. Post renal transplant patients within two years of transplantation was selected for this study as they have the highest risk of adverse outcomes due to virus infection or reactivation. We detected a prevalence of $53.7 \%$ for overall viruria and $11 \%$ for overall viraemia. We detected seven patients with significant viruria and two patients with significant viraemia, that had reached presumptive PVAN cutoffs, needing further investigation and follow up [1].

The prevalence of an infection depends on the sensitivity and specificity of the assay. The assay we used, Altona Real-star® BK virus assay, was comparable with two other commercial assays and was even more sensitive than the other two assays [3].

Cross sectional studies done on BK virus prevalence are limited. Arecent study from Sri Lanka [4] involving 15 post renal transplant patients with complications reported viruria in two patients but no viraemia. The median time after transplantation in this study was 2.6 years.

A recent study from Iran reported $41.8 \%$ viruria. A study from Kuwait reported $45 \%$ viruria and $26 \%$ viraemia in a group of patients with allograft dysfunction [5,6]. In our study the rate of viruria was somewhat higher but the rate of viraemia was comparable. The difference in rates may be due to the discrepancies in assay procedure and analytical sensitivity of the assay.

An Indian study reported incidence of viraemia of $42.9 \%$ one month post-transplant. An American follow up study reported that the highest rates of viruria (25.4\%) and viraemia $(13.7 \%)$ was at six months which then decreased at 12 months ( $20.3 \%$ and $8.6 \%$, respectively) $[7,8]$. In this study the viral load cutoff to define viruria was $\geq 2500$ copies $/ \mathrm{ml}$ and viraemia $\geq 1000$ copies $/ \mathrm{ml}$. The prevalence rates in our sample using the above viral loads were viruria $27.2 \%$ and viraemia $9.4 \%$.

Thirty five patients in our study had elevated serum creatinine. This could be due to several reasons including BK virus associated nephropathy and graft rejection. In our sample the median serum creatinine levels and the proportion with elevated serum creatinine were higher in patients with significant viraemia. Similar association was not seen with significant viruria. These results were comparable to those of a study conducted among solid organ transplant patients which demonstrated that BK virus viruria or viraemia and mycophenolate are independent risk factors for impaired renal function [9]. However, another study conducted in Hong Kong had not observed any relationship between viruria or viraemia and serum creatinine levels [10].

We observed that the median urine viral load was very low $(9.9 \mathrm{copies} / \mathrm{ml})$ and viraemia was not detected in patients with normal serum creatinine. In the vast majority of these patients clinical BK virus associated nephropathy could be excluded. Thus patients with significant viral loads require more stringent follow up to detect BK virus associated nephropathy early.

There were several limitations in our study. The lack of consensus about pre-analytical processing of urine samples was one and this may have an impact on the rate of detection and overall viral load. While pelleted urine is recommended in one study, another larger study recommends whole urine as opposed to centrifuged urine pellet $[11,12]$. Further studies are required to resolve this issue. Serum creatinine levels were extracted from existing laboratory reports, therefore there would have been interlaboratory variation.

\section{Conclusion}

Prevalence of BK virus viruria and viraemia were high among renal transplant patients within the first two years of transplantation. Significant viraemia was associated with raised serum creatinine levels. BK virus is undetectable in a significant proportion of post transplantation patients with normal serum creatinine. Prospective studies should be conducted to determine viruria and viraemia 'panic values'.

\section{Acknowledgements}

We would like to acknowledge the Medical Research Institute, Colombo for funding the study (MRI research grant 16/2014). Dr. ES Wijewickrema, Consultant Nephrologist at University Medical Unit, NHSL and Dr. ALM Nazar, Consultant Nephrologist, NHSL for their support in patient recruitment and specimen collection.

\section{Conflicts of Interest}

Authors declare that there are no conflicts of interest.

\section{References}

1. Hirsch HH, Brennan DC, Drachenberg CB, et al. Polyomavirus-associated nephropathy in renal transplantation: interdisciplinary analysis and recommendations. Transplantation 2005; 79: 1277-86.

2. Costa C \& Cavallo R. Polyomavirus-associated nephropathy. World J Transplant 2012; 2: 84-94.

3. Descamps V, Martin E, Morel V, et al. Comparative Evaluation of Three Nucleic Acid-Based Assays for BK Virus Quantification. J Clin Microbiol 2015; 53: 3822-7. 
4. Gunawardena KW, Jayamaha JS, Wijewickrama ES, Lanerolle RD. BK virus vireamia and viruria among a group of post kidney transplant patients in Sri Lanka. Ceylon Med J 2017; 62: 114.

5. Kaydani GA, Makvandi M, Samarbafzadeh A, Shahbazian H, Fard MH. Prevalence and Distribution of BK virus Subtypes in Renal Transplant Recipients Referred to Golestan Hospital in Ahvaz, Iran. Jundishapur J Microbiol 2015; 8: e16738.

6. Nampoory MR, Johny KV, Pacsa A, et al. BK virus nephropathy in renal transplant recipients in Kuwait: a preliminary report. Transplantation Proc 2005; 37: 3048-50.

7. Thakur R, Arora S, Nada R, Minz M, Joshi K. Prospective monitoring of $\mathrm{BK}$ virus reactivation in renal transplant recipients in North India. Transplant Infect Dis 2011; 13: 575-83.

8. Hirsch H H, Vincentic F, Frimand S, et al. Polyomavirus
BK Replication in De Novo Kidney Transplant Patients Receiving Tacrolimus or Cyclosporine: A Prospective, Randomized, Multicenter Study. Am J Transplant 2012; 13: $136-45$.

9. Muñoz P, Fogeda M, Bouza E, et al. Prevalence of BK Virus Replication among Recipients of Solid Organ Transplants. Clin Infect Dis 2005; 41: 1720-5.

10. Leung AY, Chan M, Tang SC, Liang R, Kwong YL. Realtime quantitative analysis of polyoma $\mathrm{BK}$ viremia and viruria in renal allograft recipients. J Virol Methods 2002; 103: 51-6.

11. Pinto GG, Antonio J, Polonia T, et al. Evaluation of different urine protocols and DNA extraction methods for quantitative detection of BK viruria in kidney transplant patients. J Virol Methods 2012; 188: 94-6.

12. Chen P, Lei Y, He X, et al. Sample Processing Effect on BK Virus Detection by Real-Time PCR in Urine Samples. Clin Lab 2016; 62: 833-7. 